\title{
URGENSI CIVIC EDUCATION DALAM KEHIDUPAN BERNEGARA
}

\author{
Asrori Mukhtarom*, Desri Arwen**, E. Kurniyati*** \\ Asrorimukhtarom84@gmail.com,desriarwen@yahoo.com,etykurniyati63@gmail.com \\ * Dosen Magister Pendidikan Agama Islam, Universitas Muhammadiyah Tangerang \\ ** Dosen Magister Pendidikan Agama Islam, Universitas Muhammadiyah Tangerang \\ *** Dosen Magister Pendidikan Agama Islam, Universitas Muhammadiyah Tangerang
}

\begin{abstract}
Civic education in each country has their respective goals in accordance with the value system and political system adopted by a country. Objectives play a very important role, because they will direct all teaching activities and color the other components. To be clear and focused, the purpose of civic education must be based on the values in the philosophy of a country, and accommodate the development of the demands and needs of society. In Indonesia, civic education aims to form good citizens who have citizenship knowledge about their rights and obligations as a citizen, citizenship skills capable of participating in state affairs, and have citizenship attitudes / values in accordance with the ideology of Pancasila. Civic education is formally provided at every level of education through subjects and courses in Civic Education. This research is a qualitative study that is a literature study (library research) that uses books and other literature as the main object.
\end{abstract}

Keywords : Objectives, Civic Education, Indonesia

\section{A. PENDAHULUAN}

Pengertian pendidikan banyak dipakai untuk mengacu pada berbagai macam pengertian, misalnya pengajaran, pertumbuhan, perkembangan, pembentukan akhlak, dan perubahan. Kata pendidikan juga melibatkan interaksi dengan berbagai macam hal, seperti keluarga, sekolah, masyarakat, dan lainnya. Meskipun memiliki berbagai makna, pendidikan merupakan sebuah kegiatan manusiawi. Tindakan mendidik memang secara khas hanya berlaku bagi sebuah kegiatan yang dilakukan oleh manusia. Inilah kekhasan yang membedakan manusia dengan binatang. Dalam konteks modern, pendidikan senantiasa diletakkan dalam kerangka kegiatan dan tugas yang ditujukan bagi sebuah generasi yang sedang ada dalam masa-masa pertumbuhan. Oleh karena itu pendidikan lebih mengarahkan dirinya pada pembentukan kepribadian individu. Proses pembentukan diri terusmenerus ini terjadi dalam ruang dan waktu yang telah direncanakan. Pendidikan dengan demikian mengacu pada setiap bentuk pengembangan diri yang bersifat terus-menerus, tertata rapi, dan terorganisasi, berupa kegiatan yang terarah untuk membentuk kepribadian secara personal dan sosial serta survive menghadapi tantangan dan kebutuhan zaman. $^{1}$

Pendidikan dalam kehidupan memiliki kedudukan yang sangat penting.

1 Sunarso, "Dinamika Pendidikan Kewarganegaraan pada Jenjang Pendidikan Dasar dan Menengah: Studi terhadap Politik Pendidikan, dan Kurikulum, pada era Orde Lama, Orde Baru, dan era Reformasi". Disertasi. Pascasarjana Universitas Negeri Yogyakarta, 2011. hal. 20-21. 
Karena kemajuan setiap bangsa dan negara ditentukan oleh kesadaran dan kepedulian warga negaranya terhadap pendidikan. Mustahil sebuah negara akan maju tanpa ditunjang oleh sumber manusia yang berkualitas. Untuk dapat mencapai sumber daya manusia yang berkualitas dan unggul, maka harus diselengarakan pendidikan.

Salah satu pendidikan yang diselenggarakan di setiap negara adalah pendidikan kewarganegaraan. Pendidikan tersebut diselenggarakan pada pendidikan formal maupun non formal. Lantas apa tujuan diselenggarakannya pendidikan kewarganegaraan?. Tulisan ini akan membahas apa pengertian pendidikan kewarganegaraan serta tujuan pendidikan kewarganegaraan sehingga pendidikan tersebut dianggap penting diselenggarakan di setiap negara. Metode dalam penelitian ini adalah kualitatif dan pendekatan dalam tulisan ini adalah Library Research.

\section{B. PEMBAHASAN}

\section{Hakikat Pendidikan Bagi Manusia}

Dalam perspektif al-Qur'an, pendidikan secara konseptual tidak dijelaskan secara terperinci, hanya terdapat term-term yang dipandang mengandung makna pendidikan yang jika digali lebih dalam dapat ditemukan pengertian pendidikan.

Ada dua kata yang sering dihubung-hubungkan dengan istilah pendidikan perspektif al-Qur'an, di antaranya yaitu al-tarbiyah dan al-ta'lim. Dalam al-Qur'an tidak ditemukan istilah altarbiyah secara eksplisit, namun dalam alQur'an terdapat istilah yang identik dengannya, yaitu al-rabb, rabbayânîi, nurabbî, ribbîyûn dan rabbânî. Semua istilah tersebut mempunyai konotasi makna yang berbeda-beda. Kata al-tarbiyah yang identik dengan akar kata rabba mempunyai arti luas, yaitu memelihara, menumbuhkan, mengembangkan, menguasai, memiliki, dan mengatur. ${ }^{2}$ Sebagaimana dalam QS. AlFatihah: 2:

Segala puji bagi Allah, Tuhan semesta alam. (QS. Al-Fatihah: 2).

Kata $R a b b$ di atas berarti Tuhan yang ditaati yang Memiliki, Mendidik dan Memelihara, Mengembangkan alam semesta secara berangsur-angsur termasuk manusia hingga sampai pada derajat yang sempurna.

Apabila istilah al-tarbiyah diidentikkan dengan bentuk fi'il madhi-nya rabbayânî sebagaimana dalam QS. al-Isra: 24, dari bentuk mudhari-nya nurabbi sebagaimana dalam QS. al-Syu'ara: 18, maka al-tarbiyah mempunyai arti mengasuh, menanggung, memberi makan, mengembangkan, memelihara, memproduksi, membesarkan dan menjinakkan. Menurut al-Razi, term rabbayânî tidak hanya pengajaran yang bersifat ucapan yang memiliki domain kognitif tetapi juga meliputi juga pengajaran tingkah laku yang memiliki domain afektif. ${ }^{3}$

Bila didasarkan pada QS. Ali Imran: 79 dan 146, pengertian al-tarbiyah (padanan kata rabbaniyyîn dan ribbiyûn) adalah transformasi ilmu pengetahuan dan sikap pada anak didik, yang mempunyai semangat tinggi dalam memahami dan menyadari kehidupannya sehingga terwujud ketakwaan, budi pekerti, dan pribadi yang luhur. Kata ini juga memiliki makna kesempurnaan ilmu dan takwanya kepada Allah Swt.

Sedangkan kata al-ta'lîm yang berasal dari kata dasar 'allama, yang berarti mengajar, menanamkan keyakinan dan pengetahuan. ${ }^{4}$ Kata al-ta'lim sendiri dapat dijumpai di dalam al-Qur'an pada surat alBaqarah: 31, kata al-ta'lim digunakan oleh Allah untuk mengajar nama-nama yang ada di alam jagat raya kepada Nabi Adam.

2 Ibrahim Anis, al-Mu'jam al-Wasit, Jakarta: Angkasa, 1972, hal. 321.

3 Fakhru al-Razi, Tafsr Fakhru al-Râzi, Teheran: Dâr al-Kutub al-'Ilmiyah, t.t, hal. 151.

4 Ibrahim Anis, al-Mu'jam al-Wasit, Jakarta: Angkasa, 1972, hal. 9. 
Berdasarkan pemahaman tentang pendidikan di atas, yang diartikulasikan dengan term al-tarbiyah dan al-ta'lîm, maka dapat diambil generalisasi bahwa kedua term tersebut memang mengisyaratkan pendidikan. Akan tetapi bila dilakukan analisis secara mendalam paling tidak dapat dikatakan bahwa alta'lìm lebih mengarah kepada aktifitas doktrinasi ilmu pengetahuan. Sedangkan $a l$ tarbiyah mengandung tiga domain pendidikan, yaitu kognitif, afektif, dan psikomotorik dan dua aspek pendidikan jasmani dan rohani. ${ }^{5}$ Penulis menyimpulkan bahwa istilah tarbiyah lebih luas maknanya, dan ta'lim termasuk unsur di dalamnya.

Walaupun istilah pendidikan tersebut di atas dapat dipahami secara berbeda, namun pada hakekatnya merupakan satu kesatuan dalam satu sistem yang utuh. Konsep dan teori kependidikan sebagaimana yang dibangun atau dipahami dan dikembangkan dari al-Qur'an, mendapatkan justifikasi dan perwujudan secara operasional dalam proses pembudayaan dan pewarisan serta pengembangan ajaran agama, budaya dan peradaban Islam dari generasi ke generasi, yang berlangsung sepanjang sejarah umat Islam. $^{6}$

\section{Urgensi Civic education Dalam Bernegara}

Di berbagai negara termasuk Indonesia, pendidikan dijadikan sebagai sarana untuk membentuk warga negaranya baik. Melalui pendidikan kewarganegaraan, harapannya setiap warga negara menjadi warga yang baik.

Istilah

"pendidikan

kewarganegaraan" dalam bahasa asing diterjemahkan dengan dua istilah, yaitu civic education dan citizenship education. Dari kedua istilah tersebut terdapat

5 Muhammad Muntahibun Nafis, Ilmu Pendidikan Islam, Yoyakarta: Teras, 2011, hal. 15.

6 Muhaimin, Paradigma Pendidikan Islam Upaya Mengefektifkan Pendidikan Agama Islam di Sekolah, Bandung; PT Remaja Rosdakarya, 2008, hal. 30. kandungan civic dan citizenship. Kata Civic, secara etimologis barasal dari masa Romawi yang pada waktu itu berbahasa Latin, yaitu "civis", "civicus", atau "civitas" yang artinya anggota atau warga dari suatu republik di zaman Romawi, sedangkan di zaman Yunani Athena diistilahkan polites, yaitu anggota dari polis (negara kota), dan dalam bahasa Inggris diartikan citizen yang berarti warga. Kata Civics (civic $+s$ ) diterjemahkan sebagai ilmu kewarganegaraan. Huruf " $s$ " yang terdapat pada kata civic menunjukkan sebuah ilmu, sama seperti economics atau politics. Civics adalah unsur dari ilmu politik yang berisi hak dan kewajiban warga negara. Civics sebagai bagian dari ilmu politik mengambil porsi dari ilmu politik, yaitu pada bagian demokrasi politik. ${ }^{7}$ Menurut Numan Soemantri, dalam penerbitan majalah "The Citizen" dan "Civics" pada tahun 1886, Hendry Randall Waite merumuskan Civics dengan "the science of citizenship" - the relation of man, the individual to man in organized collections - the individual in his relation to the state". Dari definisi tersebut, istilah Civics dapat dirumuskan dengan Ilmu Kewarganegaraan yang membicarakan hubungan manusia dengan manusia dalam perkumpulan-perkumpulan yang terorganisir (organisasi sosial, ekonomi, politik), dan individu-individu dengan negara. Dalam pengertian lain, Edmonson mendefinisikan Civics sebagai sebuah pelajaran yang membahas pemerintahan dan kewarganegaraan, hak dan kewajiban warga negara. Amerika Serikat merupakan negara perintis kegiatan akademis terkait pelajaran Civics. Menurut Creshore sebagaimana dikemukakan Numan Soemantri, untuk pertama kalinya pada tahun 1790 di Amerika Serikat mulai diperkenalkan mata pelajaran Civics sebagai mata pelajaran di sekolah. Tujuan diberikannya pelajaran Civics saat itu adalah untuk "meng-Amerikakan" bangsa

7 Winarno, Pembelajaran Pendidikan Kewarganegaraan: Isi, Strategi, dan Penilaian, Jakarta: Bumi Aksara, 2014, hal. 1-2.

Tadarus Tarbawy. Vol. 1 No. 2 Jul - Des 2019. ISSN. 2657-1285 e-ISSN. 2656-8756 
Amerika atau terkenal dengan theory of Americanization. ${ }^{8}$

Pada perkembangannya, pengertian Civics bukan hanya meliputi hak dan kewajiban warga negara dan struktur pemerintahan saja, tetapi ditambah dengan materi kewarganegaraan yang berhubungan dengan kemasyarakatan atau lingkungan sosial (community civics), prisip-prinsip ekonomi dalam pemerintahan (economic civics), dan mata pencaharian (vocational civics). Setelah mendapatkan pelajaran Civics, harapannya siswa memiliki keterampilan sosial, kompetensi warga negara, serta watak yang baik.

Istilah Citizenship secara umum diterjemahkan dengan kewarganegaraan. Kewarganegaraan berarti seperangkat karakter sebagai warga. Kewarganegaraan menunjukkan keanggotaan dalam komunitas politik. Kewarganegaraan membawa implikasi pada kepemilikan hak untuk berpartisipasi dalam politik. Roger M. Smith sebagaimana dikutip Winarno mengidentifikasikan adanya empat makna dari kewarganegaraan. (1) A citizen is a person with plitical rights to participate in the processes of popular self-governance (rights to vote; to hold elective appointive governmental offices; to serve on various sorts of juries; and to participate in political debates as equal community members, etc). (2) In modern world, citizenship is a more purely legal status. Citizens are people who are legally recognized as members of a particular, afficially sovereign political community. (3) In the last century, citizens refer to those who belong to almost any human association, whether a political community or some other groups (neighborhood, fitness club, university and broader political community). (4) Citizenship signifies not just membership in some groups but certain standards of proper conducts Contributors, not free-riders, are considered "true citizens" of those bodies.

\footnotetext{
${ }^{8}$ Numan Soemantri, Metode Mengajar Civics, Jakarta: Penerbit Erlangga, 1976, hal. 31.
}

Berdasarkan pendapat M. Roger tersebut, maka kewarganegaraan dapat dipahami sebagai hak, yaitu hak politik untuk berpartisipasi dalam proses pemerintahan; sebagai status hukum, yang secara sah diakui sebagai anggota dari komunitas politik (negara) yang berdaulat; keanggotaan dari suatu komunitas, kewarganegaraan menunjuk pada asosiasi/keterikatan orang tidak hanya pada negara, tetapi juga komunitas lain (seperti keluarga, klub, universitas, dan komunitas politik yang lebih luas lagi); dan seperangkat tindakan, artinya kewarganegaraan tidak hanya mengimplikasikan adanya keanggotaan, tetapi juga ketentuan-ketentuan dan perilaku warga negara. ${ }^{9}$ Bryan $S$ Turner sebagaimana dikemukakan Sunarso menyatakan Citizenship as that set of practices (judicial, political, economic, and cultural) which as a consequence shape the flow of resources to person and social groups. Kewarganegaraan merupakan seperangkat praktik atau tindakan yang mencakup yudisial, politik, ekonomi dan budaya yang dapat menentukan seseorang sebagai anggota masyarakat yang kompeten, sebagai konsekuensinya membentuk aliran sumber daya kepada orang-orang dan kelompok-kelompok sosial. Apa yang dikemukakan oleh Turner ini bahwa konsep kewarganegaraan sebenarnya bukan semata-mata seperangkat hak yang bersifat pasif yang diberikan oleh negara pada warganya. Tetapi menurutnya kewarganegaraan merupakan seperangkat tindakan baik secara hukum, politik, ekonomi, dan budaya, yang dapat dilakukan warga sebagai anggota dari komunitas. ${ }^{10}$

9 Winarno, Pembelajaran Pendidikan Kewarganegaraan: Isi, Strategi, dan Penilaian, Jakarta: Bumi Aksara, 2014, hal. 3-4.

10 Sunarso, "Dinamika Pendidikan Kewarganegaraan pada Jenjang Pendidikan Dasar dan Menengah: Studi terhadap Politik Pendidikan, dan Kurikulum, pada era Orde Lama, Orde Baru, dan era Reformasi". Disertasi. Pascasarjana Universitas Negeri Yogyakarta, 2011, hal. 49.

Tadarus Tarbawy. Vol. 1 No. 2 Jul - Des 2019. ISSN. 2657-1285 e-ISSN. 2656-8756 
Dari uraian tersebut menunjukkan bahwa menjadi warga negara tidak hanya sebatas anggota sebuah komunitas, tetapi memerlukan seperangkat karakter, perilaku, dan sikap yang muncul dari keanggotaan itu. Warga bukan hanya anggota suatu komunitas politik negara atau disebut warga negara, tetapi juga anggota dari komunitas lainnya.

Para pakar membedakan makna dari istilah civic education dan citizenship education. Menurut John J. Cogan sebagaimana yang dikutip Winarno, civic education yaitu pendidikan kewarganegaraan dalam arti sempit, yaitu sebagai bentuk pendidikan formal, seperti mata pelajaran, mata kuliah, atau kursus di lembaga sekolah, universitas, atau lembaga formal lainnya. Sedangkan citizenship education mencakup tidak hanya sebagai bentuk formal pendidikan kewarganegaraan, tetapi bentuk-bentuk informal dan non formal pendidikan kewarganegaraan.

Istilah civic education oleh Cogan dan Derricott sebagaimana yang dikemukakan Lili Halimah, mengacu kepada suatu mata pelajaran dasar di sekolah yang dirancang untuk mempersiapkan warga negara muda, agar kelak setelah dewasa dapat berperan aktif dalam masyarakatnya. Sementara istilah citizenship education mencakup pengalaman belajar di sekolah maupun di luar sekolah, seperti yang terjadi di dalam lingkungan keluarga, organisasi keagamaan, organisasi kemasyarakatan, dan dalam media yang membantunya untuk menjadi warga negara seutuhnya. ${ }^{11}$ Udin S Winataputera mengemukakan bahwa citizenship education lebih luas lagi cakupannya, artinya pendidikan kewarganegaraan bukan hanya diajarkan di

11 Lili Halimah, "Harmonisasi Nilai Kosmopolitan dan Etnisitas Melalui Pembelajaran Pendidikan Kewarganegaraan Pengaruhnya Terhadap Nasionalisme Siswa (Penilitian CrossSectional Survey Pada Siswa Sekolah Menengah di Kota Cimahi”. Disertasi. Pascasarjana Universitas Pendidikan Indonesia, 2014, hal. 16. lembaga pendidikan formal saja seperti Sekolah Dasar sampai Perguruan Tinggi, tapi juga di luar sekolah baik yang berupa program penataran atau program yang lainnya yang berfungsi memfasilitasi proses pendewasaan atau pematangan sebagai warga negara yang cerdas dan baik. ${ }^{12}$

$$
\text { Istilah Civic Education }
$$

diterjemahkan menjadi Pendidikan

Kewarganegaraan (memakai huruf besar diawal) dan citizenship education diterjemahkan menjadi pendidikan kewarganegaraan (semuanya dengan huruf kecil). Istilah Pendidikan Kewarganegaraan (PKn) menunjuk kepada suatu mata pelajaran, sedangkan pendidikan kewarganegaraan menunjuk pada kerangka konseptual sistemik program pendidikan untuk kewarganegaraan yang dapat ditulis dengan semuanya huruf besar atau huruf kecil. $^{13}$

Dari penjelasan para pakar di atas terkait makna civic education dan citizenship education, penulis dapat menyimpulkan bahwa istilah citizenship education suatu konsep yang lebih luas di mana civic education termasuk bagian penting di dalamnya. Civic education bagian dari citizenship education. Pada tulisan ini, istilah pendidikan kewarganegaraan pada dasarnya digunakan istilah yang lebih luas yaitu citizenship education yang mencakup pendidikan di lembaga pendidikan formal (dalam hal ini di sekolah) maupun di luar sekolah seperti penataran, seminar, workshop, dan pelatihan atau program lainnya yang sengaja dirancang untuk memfasilitasi proses pendewasaan atau pematangan sebagai warga negara yang cerdas dan baik.

12 Udin S. Winataputra, "Jati Diri Pendidikan Kewarganegaraan Sebagai Wahana Pendidikan Demokrasi”. Disertasi. Pascasarjana UPI, 2001, hal. 20-21.

13 Masrukhi, "Manajemen Pembelajaran Pendidikan Kewarganegaraan Sebagai Pembangun Karakter (Penelitian pada Beberapa Sekolah Dasar di Semarang)". Disertasi. Pascasarjana Universitas Negeri Semarang, 2008, hal. 71. 
Setiap negara pasti menginginkan warga negaranya cerdas dan baik. Oleh karena itu, usaha setiap negara dalam rangka membina terhadap generasi mudanya menjadi warga negara yang baik menjadi perhatian utama. Menurut Dasim Budimansyah, tidak ada tugas yang lebih penting dari pengembangan warga negara yang baik dan bertanggung jawab. Demokrasi dipelihara oleh warga negara yang mempunyai pengetahuan, kemampuan dan karakter yang dibutuhkan. Tanpa adanya komitmen yang benar dari warga negara terhadap nilai dan prinsip fundamental demokrasi, maka masyarakat yang terbuka dan bebas, tak mungkin terwujud. Oleh karena itu, tugas bagi pendidik, pembuat kebijakan, dan anggota masyarakat madani (civil society) lainnya adalah mengkampanyekan atau mensosialisasikan pentingnya pendidikan kewarganegaraan kepada seluruh lapisan masyarakat dan semua instansi dan jajaran pemerintahan. ${ }^{14}$

Pendidikan kewarganegaraan pada dasarnya suatu upaya pemerintah untuk mendidik dan mengembangkan karakter warga negaranya sesuai dengan ideologi serta politik bangsanya. Menurut Sunarso, pendidikan kewarganegaraan merupakan pendidikan politik yang memiliki tujuan bagaimana membina dan mengembangkan warga negara yang baik, yakni warga negara yang mampu berpartisipasi serta bertanggung jawab dalam kehidupan berbangsa dan bernegara. ${ }^{15}$ Selain itu, kesadaran dan partisipasi warga negara

\footnotetext{
14 Dasim Budimansyah, "Tantangan Globalisasi Terhadap Pembinaan Wawasan Kebangsaan dan Cinta Tanah Air di Sekolah". Makalah dalam Seminar Bersama UPI-UPSI dengan tema "Pembinaan Warga Negara yang Cerdas dan Baik (Smart and Good Citizen): Pengalaman Indonesia dan Malaysia", UPSI Malaysia, 14 April 2010, hal. 1 .

Sunarso, "Dinamika Pendidikan Kewarganegaraan pada Jenjang Pendidikan Dasar dan Menengah: Studi terhadap Politik Pendidikan, dan Kurikulum, pada era Orde Lama, Orde Baru, dan era Reformasi”. Disertasi. Pascasarjana Universitas Negeri Yogyakarta, 2011, hal. 52.
}

yang dibangun dalam bidang hukum dan moral kepribadian warga negara yang utuh di masyarakat multikultur dapat ditumbuhkembangkan melalui pendidikan kewarganegaraan.

Pendidikan kewarganegaraan dapat diselenggarakan di sekolah (melalui mata pelajaran Pendidikan Kewarganegaraan) maupun di luar sistem persekolahan, misalnya penyelenggaraan seminar terkait kebangsaan, diskusi publik terkait bela negara, dan lain sebagainya. Di sekolah, pelajaran Pendidikan Kewarganegaraan merupakan salah satu bidang kajian dalam konteks pendidikan yang memiliki peran strategis untuk meningkatkan kembali wawasan kebangsaan, semangat nasionalisme, serta membentuk warga negara yang baik sesuai dengan falsafah bangsa dan konstitusi negara, sekaligus untuk menjawab tantangan perkembangan demokrasi dan integrasi nasional. Selain itu, pendidikan kewarganegaraan diselenggarakan untuk memupuk kesadaran bela negara, cara berpikir yang komprehensif integralistik dalam rangka ketahanan nasional untuk kelangsungan hidup dan kejayaan bangsa dan negara. Kesadaran tersebut mencakup kecintaan kepada tanah air, kesadaran berbangsa, bernegara dan bermasyarakat, serta keyakinan akan kebenaran falsafah negara. Kesadaran tersebut harus ada dalam jiwa warga negara, terlebih dalam kehidupan berbangsa, bernegara dan bermasyarakat yang tak bisa dilepaskan dari masalahmasalah seperti konflik yang terjadi pada sebuah negara yang masyarakatnya majemuk termasuk Indonesia yang memiliki keanekaragaman suku, agama, ras, dan budaya. Satu sisi, kanekaragaman tersebut merupakan kekayaan sebuah bangsa, tetapi pada sisi lain dalam keanekaragaman tersebut terdapat potensi konflik yang dilatarbelakangi masalah identitas (perbedaan agama, etnis, dan budaya). Konflik yang telah terjadi di beberapa wilayah merupakan akumulasi akan turunnya kesadaran cinta tanah air dan kerapuhan persatuan dan kesatuan 
masyarakat. Menghadapi realita tersebut, disinilah urgensi pendidikan kewarganegaraan sebagai upaya strategis dalam membina dan membimbing masyarakat akan pentingnya kesatuan dan persatuan.

Selain konflik, masalah terorisme pun menjadi ancaman bagi setiap negara. Adanya tragedi kemanusiaan yang disebabkan tindakan terorisme tentunya berdampak pada keamanan wilayah dalam sebuah negara. Salah satu sektor yang paling dirugikan atas dampak terorisme adalah sektor pariwisata. Negara yang menjadi korban atas tindakan terorisme akan merugi, oleh karenanya beberapa negara memberikan travel warning dengan alasan keamanan bagi warga negaranya.

Salah satu upaya preventif dalam penanggulangan terorisme yaitu melalui pendidikan kewarganegaraan yang meliputi pendidikan sosial dalam rangka mengembangkan tanggung jawab sosial warga masyarakat, pentingnya toleransi dan kerukunan dalam perbedaan, cinta tanah air, dan cinta damai. Dengan demikian pendidikan kewarganegaraan memiliki urgensi dalam membentuk warga negara yang baik secara individu maupun sosial.

Globalisasi yang terus berkembang dan terjadi di hampir seluruh negara di dunia yang ditandai dengan kemajuan di bidang teknologi komunikasi dan informasi tentunya memiliki dampak positif dan negatif. Dampak positif dari kemajuan teknologi komunikasi dan informasi yaitu memberikan kemudahan dalam mengakses informasi penting terkait pekembangan dan peristiwa yang terjadi di dunia. Sedangkan dampak negatif dari kemajuan teknologi komunikasi dan informasi adalah tidak adanya batasan terkait informasi yang masuk silih berganti yang datangnya dari negara-negara lain. Melalui media informasi, ideologi dan gaya hidup hedonis, individualis, dan konsumtif di beberapa negara maju di Barat dapat mempengaruhi kebiasaan dan nilai-nilai dasar masyarakat Timur yang terkenal santun, religius, dan memiliki kolektivisme kuat. Dan pengaruh budaya luar apabila tidak disikapi dengan wawasan dan pemahaman yang benar akan menjadikan adanya kesalahan penafsiran yang dapat mengakibatkan terjadinya kesalahan persepsi.

Melihat fenomena yang terjadi yang dijelaskan di atas, maka peran pendidikan kewarganegaraan sangat strategis. Pendididikan kewarganegaraan bukan hanya dituntut untuk dapat menyiapkan generasi mudanya untuk menjadi warga negara yang baik. Namun, pendidikan kewarganegaraan juga harus bisa menyiapkan generasi mudanya menjadi generasi yang dapat berperan aktif dalam ranah global serta mampu memfilter pengaruh negatif globalisasi. Mengingat saat ini kita berada di era globalisasi yang memiliki kecenderungan terintegrasinya kehidupan masyarakat domestik ke dalam komunitas global.

Menurut Sjoerd Karsten, ada tujuh kecenderungan global yang perlu diantisipasi oleh setiap negara, yaitu:

1. Kesenjangan ekonomi antar negara akan semakin meluas secara signifikan;

2. Informasi teknologi secara dramastis akan mengurangi privasi individu;

3. Peningkatan perbedaan antara mereka yang memiliki dan tidak memiliki akses terhadap teknologi informasi;

4. Konflik kepentingan antara negara maju dan berkembang akan meningkat;

5. Biaya untuk memperoleh air bersih akan naik secara dramatis karena pertumbuhan penduduk dan kerusakan lingkungan;

6. Penggundulan hutan secara dramatis akan mempengaruhi keragaman kualitas hidup;

7. Pertumbuhan penduduk di negara berkembang akan menyebabkan peningkatan populasi terutama anakanak yang hidup dalam kemiskinan. ${ }^{16}$

16 Mukhamad Murdiono, "Pendidikan Kewarganegaraan Untuk Membangun Wawasan Global Warga Negara Muda". Dalam Jurnal Cakrawala Pendidikan, No. 3 Edisi Oktober, Universitas Negeri Yogyakarta, 2014, hal. 350.

Tadarus Tarbawy. Vol. 1 No. 2 Jul - Des 2019. ISSN. 2657-1285 e-ISSN. 2656-8756 
Permasalahan-permasalahan global yang dialami suatu negara dan lintas negara perlu pemecahan. Disinilah urgensi pendidikan kewarganegaraan yang memiliki peran strategis dalam membangun wawasan global warga negara. Pendidikan kewarganegaraan tidak sebatas mempelajari hak dan kewajiban warga negara, melainkan lebih luas dan mendalam termasuk mempersiapkan warga negara menjadi warga global. Pendidikan kewarganegaraan membekali peserta didik di sekolah dengan pengetahuan isu-isu global, budaya, lembaga dan sistem internasional. Sehingga lewat pendekatan tersebut, maka peserta didik akan mampu memfilter pengaruh global yang negatif, lebih hati-hati, teliti, dan bertanggung jawab.

Menurut Morais dan Ogden, ada tiga dimensi yang dapat dikembangkan sebagai upaya mempersiapkan warga negara global yang baik dalam pembelajaran pendidikan di sekolah, yaitu tanggung jawab sosial, kompetensi global, dan keterlibatan dalam kewargaan global. ${ }^{17}$ Berikut penjelasannya:

1. Tanggung jawab sosial (social responsibility)

Tanggung jawab sosial dimaknai sebagai tingkat kesadaran saling ketergantungan dan kepedulian sosial kepada orang lain, masyarakat, dan lingkungan. Siswa dilatih untuk saling menghormati perbedaan budaya lintas negara, serta dilatih mengembangkan tanggung jawab sosial dengan cara ikut serta mengevaluasi masalah-masalah sosial dan mengindentifikasi kasus atau contoh-contoh ketidakadilan dan kesenjangan global.

2. Kompetensi global (global competence) Kompetensi global diartikan sebagai kemampuan memiliki pikiran yang terbuka dan secara aktif berusaha

17 B.D Morais dan Ogden, "Initial Development and Validation of the Global Citizenship Scale". Dalam Journal of Studies in International Education No. 15, 2011, hal. 447. memahami norma-norma budaya orang lain dan memanfaatkan pengetahuan yang dimiliki untuk berinteraksi, berkomunikasi, dan berkerja secara efektif.

3. Keterlibatan dalam kewargaan global (global civic engagement)

Keterlibatan dalam kewargaan global dimaknai sebagai tindakan dan atau kecenderungan untuk mengenali masalah-masalah kemasyarakatan baik di tingkat lokal, regional, nasional, maupun global dan menanggapinya melalui tindakan seperti kesukarelaan, aktifitas politik, dan partisipasi masyarakat.

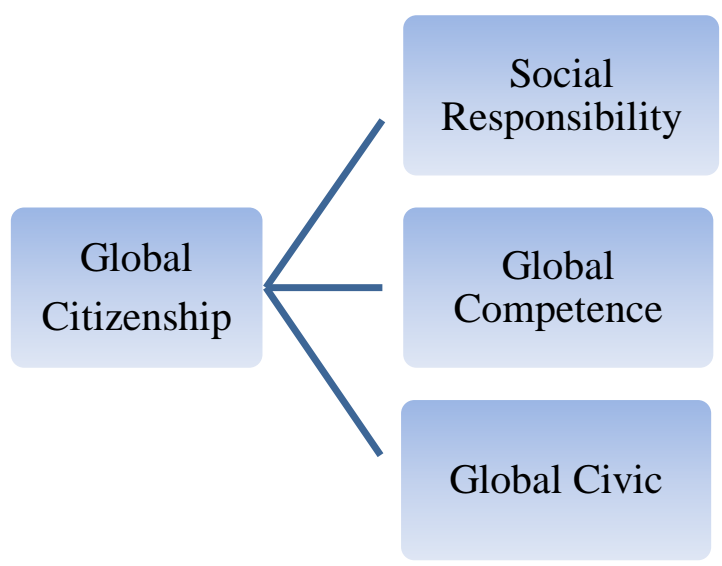

(Global citizenship conceptual model oleh Morais dan Ogden)

Tiga dimensi global yang telah dijelaskan di atas, menjadi nilai-nilai dasar yang penting untuk dikembangkan dalam pendidikan kewarganegaraan global. Akhirnya, pendidikan kewarganegaraan bukan hanya memberikan pemahaman sebagai warga negara dalam suatu masyarakat. Tetapi juga memberikan pemahaman akan peranan sebagai warga negara sebagai warga global yang cerdas dan baik.

Pembangunan sebuah negara baik dalam bidang ekonomi, politik, sosial, budaya, pertahanan, dan keamanan tidak akan berhasil jika tidak didukung oleh partisipasi warga negaranya. Oleh karena itu, melalui pendidikan kewarganegaraan dapat merangsang dan menumbuhkan 
partisipasi aktif warga negara dalam pembangunan negara. Pendidikan kewarganegaraan memiliki misi menumbuhkan partisipasi masyarakat dalam memahami kebutuhan pembangunan, permasalahan

pembangunan, dan pelaksanaan pembangunan.

\section{Pelajaran}

Pendidikan

Kewarganegaraan di tiap-tiap negara memiliki tujuan masing-masing sesuai dengan sistem nilai dan sistem politik yang dianut oleh suatu negara. Tujuan memegang peranan yang sangat penting, karena akan mengarahkan semua kegiatan pengajaran dan mewarnai komponen-komponen lainnya. Agar jelas dan terarah, maka tujuan pendidikan kewarganegaraan harus didasari oleh nilai-nilai dalam falsafah sebuah negara, serta mengakomodir perkembangan tuntutan dan kebutuhan masyarakat.

Yang menjadi objek dalam kajian pendidikan kewarganegaraan adalah warga negara dalam hubungannya dengan organisasi kemasyarakatan, sosial ekonomi, agama, kebudayaan, dan negara. Oleh karenanya, tujuan akhir dari pendidikan kewarganegaraan adalah terbentuknya warga negara yang baik (a good citizen) ${ }^{18}$

Ada beberapa pendapat para ahli terkait tujuan pendidikan kewarganegaraan, di antaranya:

${ }^{18}$ Pengertian warga negara yang baik pada masa-masa lalu lebih diartikan sesuai dengan tafsir penguasa. Pada masa Orde Lama, warga negara yang baik adalah warga negara yang berjiwa "revolusioner", anti imperialisme, kolonialisme, dan neo kolonialisme. Pada masa Orde Baru, warga negara yang baik adalah warga negara yang Pancasilais, manusia pembangunan dan sebagainya. Sejalan dengan visi Pendidikan Kewarganegaraan era Reformasi, misi mata pelajaran ini adalah meningkatkan kompetensi siswa agar mampu menjadi warga negara yang berperan serta secara aktif dalam sistem pemerintahan negara yang demokratis. Sunarso, "Warga Negara dan Pendidikan Kewarganegaraan (Kajian Konsep dan Sejarahnya)". Hasil Penelitian. Universitas Negeri Yogyakarta, 2009, hal 22.
1. Menurut David Kerr, tujuan pendidikan kewarganegaraan adalah preparation of young people for their roles an responsibilities as citizens (mempersiapkan generasi muda untuk mengambil peran dan tanggung jawabnya sebagai warga negara). ${ }^{19}$

2. Menurut Numan Soemantri, tujuan pendidikan kewarganegaraan adalah mendidik warga negara yang baik, yang dapat dilukiskan dengan warga negara yang patriorik, toleran, loyal terhadap bangsa dan negara, beragama, dan demokratis. ${ }^{20}$

Menurut Udin S Winataputra, di Indonesia secara holistik pendidikan kewarganegaraan bertujuan agar setiap warga negara muda (young citizens) memiliki rasa kebangsaan dan cinta tanah air dalam konteks nilai dan moral Pancasila, nilai dan norma Undang-Undang Dasar Negara Republik Indonesia 1945, nilai dan komitmen Bhinneka Tunggal Ika, dan komitmen bernegara kesatuan Republik Indonesia. Menurutnya, pendidikan kewarganegaraan harus dirancang dalam konteks pengembangan kecerdasan kewarganegaraan (civic intelligence) yang secara psikososial tercermin dalam penguasaan pengetahuan kewarganegaraan (civic knowledge), perwujudan sikap kewarganegaraan (civic dispositions), penampilan keterampilan kewarganegaraan (civic skills), pemilikan komitmen kewarganegaraan (civic commitment), pemilikan keteguhan kewarganegaraan (civic confident), dan penampilan kecakapan kewarganegaraan (civic competence) yang kesemuanya itu memancar dari dan mengkristal kembali menjadi kebajikan/keadaban kewarganegaraan (civic virtues/civility). Keseluruhan kemampuan itu merupakan

19 David Kerr, "Citizenship Education In The Curriculum: An International Review". Dalam The School Field, Volume X No 3-4, London, t.t, National Foundation for Educational ResearchNFER, hal. 6.

20 Numan Soemantri, Metode Mengajar Civics, Jakarta: Penerbit Erlangga, 1976, hal. 28. 
pembekalan bagi setiap warga negara untuk secara sadar melakukan partisipasi kewarganegaraan (civic participation) sebagai perwujudan dari tanggung jawab kewarganegaraan (civic responsibility). ${ }^{21}$

Belajar dari apa yang dilakukan bangsa-bangsa lain dalam pendidikan kewarganegaraannya, upaya serupa telah dilakukan di Indonesia. Tujuan pendidikan kewarganegaraan di antaranya dalam rangka meng-Indonesia-kan bangsa Indonesia. Sebab meskipun secara yuridis formal seseorang sebagai warga negara Indonesia (WNI) tetapi bisa saja karakternya bukan sebagai bangsa Indonesia. Oleh karena itu, tujuan pendidikan kewarganegaraan adalah mengIndonesia-kan orang Indonesia dari berbagai aspek, baik sosial maupun budaya. Sebagai bangsa yang majemuk diharapkan melalui mata pelajaran Pendidikan Kewarganegaraan dapat dibina warga negara yang memahami dan melaksanakan dengan baik hak-hak dan kewajibannya sebagai warga negara. ${ }^{22}$

Menurut Winarno, secara komprehensif integralistik, tujuan pelajaran Pendidikan Kewarganegaraan yang diberikan kepada peserta didik sebagai berikut: ${ }^{23}$

1. Berpikir secara kritis, rasional, dan kreatif dalam menaggapi isu kewarganegaraan;

2. Berpatisipasi secara aktif dan bertanggung jawab, dan bertindak secara cerdas dalam kegiatan bermasyarakat, berbangsa, dan bernegara, serta anti korupsi;

${ }^{21}$ Udin S Winataputra, "Dinamika Aktual Tentang Paradigma Pendidikan Kewarganegaraan Dalam Konteks Kurikulum 2013”. Makalah dalam Seminar Nasional PKn-AP3KnI, 2014, hal. 4-5.

${ }^{22}$ Sunarso, "Warga Negara dan Pendidikan Kewarganegaraan (Kajian Konsep dan Sejarahnya)". Penelitian. Universitas Negeri Yogyakarta, 2009, hal 22.

${ }^{23}$ Winarno, "Pendidikan Kewarganegaraan Persekolahan: Standar Isi dan Pembelajarannya". Jurnal Civics Volume 3 No. 1 Juni 2006, hal. 29.
3. Berkembang secara positif dan demokratis untuk membentuk diri berdasarkan karakter-karakter masyarakat Indonesia agar dapat hidup bersama dengan bangsa-bangsa lainnya;

4. Berinteraksi dengan bangsa-bangsa lain dalam percaturan dunia secara langsung atau tidak langsung dengan memanfaatkan teknologi informasi dan komunikasi.

Dari uraian terkait tujuan pendidikan kewarganegaraan yang dilaksanakan di sekolah maupun luar sekolah, penulis dapat menyimpulkan bahwa penyelenggaraan pendidikan kewarganegaraan bertujuan membentuk warga negara yang baik yang memiliki pengetahuan kewarganegaraan tentang hak dan kewajibannya sebagai seorang warga negara, keterampilan kewarganegaraan yang mampu berpartisipasi dalam urusan kenegaraan, dan memiliki sikap/nilai kewarganegaraan sesuai dengan ideologi negaranya.

\section{KESIMPULAN}

Kedudukan pendidikan kewarganegaraan sangat strategis dalam kehidupan berbangsa dan bernegara. Hal tersebut guna mempersiapkan warga negara yang baik sesuai dengan ideologi bangsa tersebut. Di Indonesia, pendidikan kewarganegaraan telah diselenggarakan dimulai dari pendidikan dasar sampai perguruan tinggi. Setelah mengikuti pendidikan tersebut, harapannya peserta didik mampu melaksanakan apa yang menjadi kewajiban setiap warga negara dan apa yang menjadi hak setiap warga negara.

\section{DAFTAR PUSTAKA}

Anis, Ibrahim. al-Mu'jam al-Wasit, Jakarta: Angkasa, 1972.

Budimansyah, Dasim. "Tantangan Globalisasi Terhadap Pembinaan Wawasan Kebangsaan dan Cinta 
Tanah Air di Sekolah". Makalah dalam Seminar Bersama UPI-UPSI dengan tema "Pembinaan Warga Negara yang Cerdas dan Baik (Smart and Good Citizen): Pengalaman Indonesia dan Malaysia”, UPSI Malaysia, 14 April 2010.

Halimah, Lili. "Harmonisasi Nilai Kosmopolitan dan Etnisitas Melalui Pembelajaran

Pendidikan Kewarganegaraan Pengaruhnya Terhadap Nasionalisme Siswa (Penilitian Cross-Sectional Survey Pada Siswa Sekolah Menengah di Kota Cimahi”. Disertasi. Pascasarjana Universitas Pendidikan Indonesia, 2014.

Kerr, David. "Citizenship Education In The Curriculum: An International Review". Dalam The School Field, Volume X No 3-4, London, t.t, National Foundation for Educational Research-NFER.

Masrukhi. "Manajemen Pembelajaran Pendidikan Kewarganegaraan Sebagai Pembangun Karakter (Penelitian pada Beberapa Sekolah Dasar di Semarang)". Disertasi. Pascasarjana Universitas Negeri Semarang, 2008.

Morais, B.D, dan Ogden. "Initial Development and Validation of the Global Citizenship Scale". Dalam Journal of Studies in International Education No. 15, 2011.

Muhaimin, Paradigma Pendidikan Islam Upaya Mengefektifkan Pendidikan Agama Islam di Sekolah, Bandung; PT Remaja Rosdakarya, 2008.

Murdiono, Mukhamad. "Pendidikan Kewarganegaraan Untuk Membangun Wawasan Global Warga Negara Muda". Dalam
Jurnal Cakrawala Pendidikan, No. 3 Edisi Oktober, Universitas Negeri Yogyakarta, 2014.

Nafis, Muhammad Muntahibun Nafis. Ilmu Pendidikan Islam, Yoyakarta: Teras, 2011.

Al-Razi, Fakhru. Tafsr Fakhru al-Râzi, Teheran: Dâr al-Kutub al-'Ilmiyah, t.t.

Soemantri, Numan. Metode Mengajar Civics, Jakarta: Penerbit Erlangga, 1976.

Sunarso. "Warga Negara dan Pendidikan Kewarganegaraan (Kajian Konsep dan Sejarahnya)". Penelitian. Universitas Negeri Yogyakarta, 2009.

Sunarso. "Dinamika Pendidikan Kewarganegaraan pada Jenjang Pendidikan Dasar dan Menengah: Studi terhadap Politik Pendidikan, dan Kurikulum, pada era Orde Lama, Orde Baru, dan era Reformasi". Disertasi. Pascasarjana Universitas Negeri Yogyakarta, 2011.

Winarno. "Pendidikan Kewarganegaraan Persekolahan: Standar Isi dan Pembelajarannya". Jurnal Civics Volume 3 No. 1 Juni 2006.

Winarno. Pembelajaran Pendidikan Kewarganegaraan: Isi, Strategi, dan Penilaian, Jakarta: Bumi Aksara, 2014.

Winataputra, Udin S. "Jati Diri Pendidikan Kewarganegaraan Sebagai Wahana Pendidikan Demokrasi”. Disertasi. Pascasarjana UPI, 2001.

Winataputra, Udin S. "Dinamika Aktual Tentang Paradigma Pendidikan Kewarganegaraan Dalam Konteks Kurikulum 2013". Makalah dalam Seminar Nasional PKn-AP3KnI, 2014. 